\title{
Tradisi Menenun Pengrajin Bugis Pagatan di Era Globalisasi
}

\author{
Sri Hidayah \\ sri_hidayah2006@yahoo.com \\ (Program Studi Sosiologi Universitas Lambung Mangkurat)
}

\begin{abstract}
This paper has a purpose to explain the weaving tradition of Bugis Pagatan community which still carried out to maintain their identity. The focus of this study is Pagatan Weaving craftswomen in Tanah Bumbu Regency as part of Bugis Pagatan community and known for their unique cultural traditions in South Kalimantan.It is interesting to explore the influence of global culture to the weaving tradition values and strategies carried out by the craftswomen so their products can be accepted by the wide length of society.The external role of local government is also explained in strengthening the Bugis Pagatan cultural identity in Tanah Bumbu Regency.This research used descriptive qualitative method which data were collected by observation, in-depth interview, and documentation. The informants are Pagatan Weaving craftswomen in Pagatan, South Borneo. The results show that 1) Pagatan weaving is a result of negotiate by Pagatan's culture and tradition also global culture. Negotiate strategy was done by Pagatan Weaving craftswomen for its quality can fulfill international standart. 2) Government of Kabupaten Tanah Bumbu have a role in affirmation of Bugis Pagatan culture's identity.
\end{abstract}

Keywords: cultural identity, Bugis Pagatan, weaving tradition, globalization

\begin{abstract}
Abstrak
Tulisan ini bertujuan untuk memaparkan secara mendalam tradisi menenun masyarakat Bugis Pagatan yang dilakukan untuk mempertahankan identitas keBugisan mereka. Fokus kajian ini adalah komunitas pengrajin Tenun Pagatan di Kabupaten Tanah Bumbu sebagai bagian dari masyarakat Bugis Pagatan yang dikenal dengan keunikan tradisi - tradisi kebudayaannya di Kalimantan Selatan. Hal ini menarik untuk diteliti adalah sejauh mana pengaruh budaya global terhadap nilai - nilai tradisi menenun tersebut dan strategi - strategi yang dilakukan oleh komunitas pengrajin Tenun Pagatan agar produk tenunannya dapat diterima oleh masyarakat luas. Peran eksternal khususnya pemerintah daerah juga dijelaskan dalam memperkuat identitas budaya Bugis Pagatan di Kabupaten Tanah Bumbu. Metode dan pendekatan penelitian ini adalah deskriptif kualitatif. Teknik pengumpulan data kualitatif ini melalui obervasi, wawancara mendalam kepada informan pengrajin tenun pagatan di Kabupaten Pagatan, Kalimantan Selatan, dokumentasi. Hasil penelitian ini menunjukkan bahwa 1) tenun pagatan merupakan hasil negosiasi dari budaya dan tradisi Pagatan dan budaya global. Strategi negosiasi dilakukan pengrajin tenun agar kualitas tenun pagatan memenuhi standar internasional, 2) Pemerintah Daerah Kabupaten Tanah Bumbu berperan dalam penguatan identitas budaya Bugis Pagatan.
\end{abstract}

Kata kunci: identitas budaya, Bugis Pagatan, tradisi menenun, globalisasi, negosiasi. 


\section{Pendahuluan}

$\mathrm{M}$

asyarakat Bugis Pagatan di Kecamatan Kusan Hilir Kabupaten Tanah Bumbu merupakan salah satu dari etintas-etintas baru yang lahir dari migrasi orang Bugis ke wilayah-wilayah Nusantara pada abad 17. Orang Bugis Pagatan mengakui jika leluhurnya berasal dari sejumlah daerah di Sulawesi Selatan, namun tetap mengidentifikasi diri sebagai sebuah entitas tersendiri, yaitu orang Bugis Pagatan. Tradisi menenun merupakan keahlian tradisional suku Bugis yang mengandung kearifan lokal dan diteruskan secara turun temurun. Selama beratus ratus tahun Tenun Pagatan menjadi identitas Bugis di Pagatan. Helaian-helaian kainnya mengandung nilainilai budaya dan filosofis melebur dengan budaya setempat dan melahirkan perpaduan yang membedakan kain tenun ini dengan daerah lainnya di Indonesia.

Perubahan sosial yang dialami oleh masyarakat Bugis Pagatan berupa pertumbuhan dan mobilitas penduduk, modernisasi, industrialisasi, meluasnya budaya global, dan kehidupan politik melahirkan tiga hal penting. Pertama, generasi muda Bugis Pagatan sebagai penerus mulai meninggalkan tradisi-tradisi budayanya. Kedua, produkproduk kebudayaan mereka terhegemoni oleh pasar dan bernilai komersial. Ketiga, penguasa yang berperan untuk mengukuhkan produkproduk kebudayaan mereka sebagai nilai tambah daerah.

Di tengah kemajemukan Bangsa Indonesia dan desakan globalisasi, masyarakat Bugis Pagatan tetap melakukan tradisi-tradisi untuk mempertahankan identitas ke-Bugisannya. Globalisasi membuat ruang dan waktu yang semakin sempit sehingga masyarakat Bugis Pagatan di tatanan lokal terlibat ke dalam sebuah konfrontasi resiprokal masif, dimana dimensi-dimensi kebudayan manusia dijadikan sumber daya untuk penguasaan produksi dan konsumsi. Pada saat yang sama globalisasi dianggap sebagai ancaman yang mampu mengaburkan identitas kultural mereka.

Tulisan ini berbeda dari studi-studi sebelumnya yang selama ini cenderung lebih memperhatikan peran eksternal dari sisi luar masyarakat Bugis Pagatan yang melihat mereka sebagai sosok-sosok yang perlu dibantu atau dikembangkan kapasitasnya.

\section{Metode Penelitian}

Metode dan pendekatan penelitian adalah kualitatif. Fokus informan yang diwawancarai dari komunitas pengrajin Tenun Pagatan di Kabupaten Tanah Bumbu. Teknik pengumpulan data kualitatif ini melalui obervasi pada proses aktivitas ketika pengrajin menenun sehari-hari, wawancara mendalam kepada informan pengrajin tenun pagatan di Kabupaten Pagatan, Kalimantan Selatan, dokumentasi. Penelitian ini mengkaji lebih dalam strategi-strategi yang dilakukan sendiri oleh pengrajin Tenun Pagatan dalam mempertahankan tradisi menenun yang berproses dalam menyerap perubahanperubahan yang terjadi. 
Gambar 1. Perempuan Bugis Pagatan menenun rumahnya

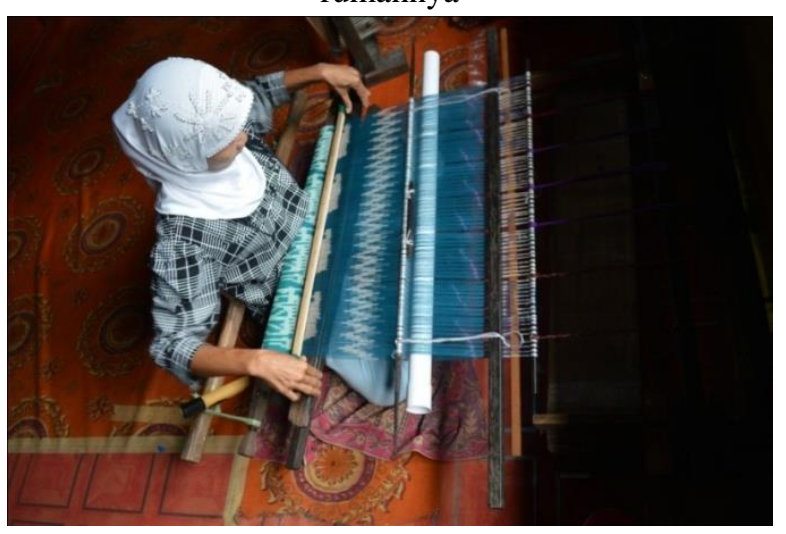

Sumber: Dokumentasi Pribadi

Melihat fenomena tersebut, peneliti mencoba mengangkat permasalahanpermasalahan sebagai berikut: pertama, bagaimana pengaruh budaya global terhadap nilai-nilai tradisi menenun yang selama ini telah dipertahankan oleh suku Bugis Pagatan?, kedua, bagaimana strategi pengrajin Tenun Pagatan agar produk-produk kebudayaannya dapat diterima oleh masyarakat luas ?, dan ketiga, Bagaimana peran eksternal khususnya pemerintah dalam memperkuat identitas budaya Bugis Pagatan di Kabupaten Tanah Bumbu?.

\section{Hasil dan Pembahasan}

\section{Diaspora orang Bugis di Tanah Bumbu}

Untuk mengenal masyarakat Bugis Pagatan, sebaiknya terlebih dahulu melihat latar belakang sejarah keberadaan mereka di Tanah Bumbu. Berdasarkan catatan sejarah, kedatangan orang-orang Bugis terbagi dalam tiga kurun waktu, yaitu migrasi pertama pada abad ke-18 sebelum berdirinya Kerajaan Pagatan, migrasi kedua saat terjadinya peperangan Bone tahun 1908 dilanjutkan dengan migrasi ke tiga abad ke 20 saat pemberontakan DI/TII Kahar Muzakkar terjadi.

Abdullah menjelaskan bahwa bahwa diaspora awal orang-orang Bugis ke daerah lain di Nusantara hingga ke Semenanjung Malaya serta wilayah Asia Tenggara lainnya dilatarbelakangi oleh faktor ekonomi dan politik serta semangat untuk merantau (massompe'). Upaya pembukaan daerah potensial di wilayah Tanah Bumbu oleh orang-orang Bugis dan strategi adaptasi ekonominya tidak jauh berbeda dengan pembentukan komunitas Bugis di wilayahwilayah lainnya. Terdapat pula kelompokkelompok nelayan Bugis yang pada awalnya hanya mencari ikan di Pagatan, berangsurangsur membawa keluarga mereka menetap di sana, yang dikenal dengan istilah pappagatang.

Gambar 2. Orang Bugis Pagatan di depan rumahnya

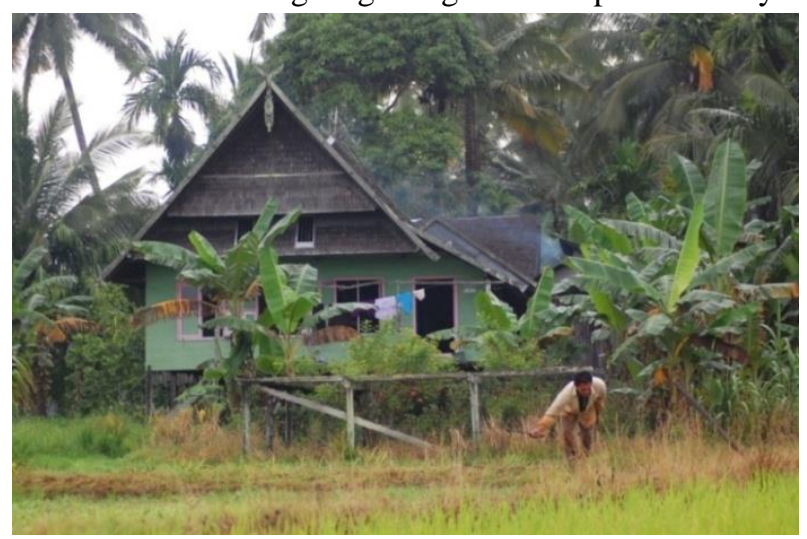

Sumber: Dokumentasi Peneliti

Diaspora orang Bugis di wilayah Borneo (Kalimantan) bagian selatan dan timur khususnya di wilayah Tanah Bumbu, seakan 'belum tersentuh' dibandingkan di Semenanjung Malaya, Riau atau wilayah Asia Tenggara lainnya. Mansyur (2012), 
menjelaskan bahwa migran Wajo yang datang ke Tanah Bumbu memiliki fleksibilitas yang luar biasa dalam beradaptasi dengan kondisi lokal di daerah di mana mereka menetap. Sementara itu, tiap komunitas Bugis yang berkembang di daerah tujuan bisa bekerja sama dan memiliki strategi sehingga bisa membaur.

Walaupun wilayah Pagatan saat ini tidak lebih dari sebuah ibukota kecamatan setelah Kerajaan Pagatan dihapus oleh Belanda pada tanggal 1 Juli 1912, Pagatan tetap melekat sebagai simbolis keBugisan mereka dan membedakan mereka dengan perantauperantau Bugis yang lain di daerah Batu Licin, Kota Baru dan sekitarnya. Bahkan orang kebanyakan berasumsi bahwa seseorang yang bertempat tinggal di Pagatan pasti orang Bugis. Sebagian besar masyarakat Bugis Pagatan bermukim di wilayah pesisir pantai dan belahan sungai sebagai nelayan atau buruh - buruh kapal, kemudian menyebar ke wilayah daratan dan pegunungan untuk membuka lahan pertanian, peternakan perikanan dan perkebunan.

Sebagai orang pendatang, orang Bugis Pagatan dikenal sebagai pekerja keras dan ulet. Ammarel (2002: 51-67) dan Saleh (2009) memaparkan bahwa perantau-perantau Bugis memiliki kemampuan dalam menciptakan peluang-peluang usaha yang belum terbuka sebelumnya ditambah dengan kemampuan membangun relasi dengan masyarakat sekitar sehingga menjadikan mereka orang-orang yang berhasil. Dominasi orang Bugis pada sektor sosial budaya, ekonomi, dan politik disebabkan oleh kemampuan mereka beradaptasi dengan komunitas lain, khususnya orang-orang Banjar sebagai penduduk asli Kalimantan. Orang
Bugis memiliki sejumlah keunggulan dalam bidang pertanian, perikanan, kelautan, dan perdagangan, serta memiliki etos kerja yang tinggi yang bersumber dari nilai-nilai budaya siri na pesse (harga diri dan rasa iba) serta filosofi hidup orang Bugis lainnya

Masyarakat Bugis Pagatan dikenal sebagai orang-orang yang masih kuat memegang tradisi untuk mempertahankan identitas mereka. Warisan-warisan budaya yang masih dilaksanakan hingga kini adalah ritual-ritual saat memperingati hari-hari besar keagamaan, pernikahan dan upacara adat. Bahkan mereka masih melakukan ritual-ritual budaya yang saat ini sudah tidak ditemukan lagi di daerah asalnya, sebagai contoh adalah acara tahunan Mappanre tasiq atau melarung laut. Satu bulan sebelum acara puncak mereka melakukan berbagai persiapan pertunjukan seni dan budaya yang dipusatkan di Pagatan dengan menyajikan pendukungnya seperti makanan tradisional dan kain-kain tenun yang indah.

Perkampungan-perkampungan Bugis Pagatan terdapat di pinggiran pantai dan wilayah persawahan. Rumah-rumah mereka di pinggiran pantai lebih padat dibandingkan dengan di daerah persawahan yang dikelilingi oleh kebun kelapa yang luas. Bahasa Bugis masih dipergunakan sehari-hari dalam berinteraksi dengan tetangga, lingkungan keluarga, bertransaksi jual beli di pasar dan kegiatan-kegiatan sosial di mesjid atau kantor desa. Nama-nama jalan di Pagatan masih ditulis dengan huruf Lontara dan diterjemahkan ke dalam bahasa Indonesia.

Perempuan-perempuan Bugis Pagatan masih mempertahankan tradisi menenun. Mereka tersebar di desa-desa pesisir pantai, pinggiran sungai Kusan dan di daerah persawahan. Walaupun jumlah mereka turun 
drastis sejak masa kejayaannya tahun 1980 1990 an, masih terdapat kurang lebih 80 orang perempuan Pagatan yang aktif dalam kegiatan menenun. Balai Arkeologi dan Museum Lambung Mangkurat memasukkan menenun sebagai salah satu mata pencaharian utama orang Bugis Pagatan dari dulu hingga sekarang. Hasil tenunan yang indah biasanya dipakai saat acara pernikahan, upacaraupacara kebudayaan mereka dan dipamerkan di acara tahunan Mappanre tasiq atau melarung laut.

Unsur-unsur dasar yang berperan di dalam corak dan motif Tenun Pagatan menyimpan bukti kuat yang legal sebagai suatu proses pewarisan nilai budaya yang dapat diteruskan kepada generasi berikutnya. Kain tradisi Tenun Pagatan merupakan contoh jelas di dalam peristiwa budaya dari suatu kekuatan struktur sosial yang pernah hilang dan tersingkirkan dari tatanan sosial Suku Bugis Wajo di Sulawesi Selatan. Kemudian ini hadir kembali sebagai corak budaya pada masyarakat pesisir pantai di Pagatan.

Masyarakat Pagatan yang hidup sekarang adalah generasi ke 5 sejak berdirinya Kerajaan Pagatan di abad 18. Generasi terdahulunya lebih dikenal lebih kuat dalam mempertahankan tradisi daripada generasi saat ini. Generasi ke 5 yang menjadi fokus penelitian ini adalah masyarakat Pagatan yang telah mengalami perubahan yang membedakan mereka dengan orang Bugis Pagatan sebelumnya.

"In a sense, this is no different from most ethnic groups. The first generation of new arrivals often maintains some strong community ties that continue to hold them together as a linguistic and cultural community, while the second generation of children who are born or raised in the new country tends to venture further into the broader community and prefers to mix socially with other groups".(Lee, 2010 : 18)

Masyarakat Bugis Pagatan saat ini menjalani kehidupan yang kompleks di tatanan lokal terlibat ke dalam sebuah konfrontasi resiprokal masif, dimana dimensidimensi kebudayan manusia dijadikan sumber daya untuk penguasaan produksi dan konsumsi. Pada saat yang sama globalisasi dianggap sebagai ancaman yang mampu mengaburkan identitas kultural mereka.

\section{Konsep Kebudayaan dan Tradisi Menenun}

Kain dalam tradisi budaya Indonesia telah dilalui dalam perjalanan waktu yang sangat panjang. Tradisi tenun tersebar merata hampir di seluruh wilayah di Indonesia. Letak Indonesia yang berada di tengah-tengah persimpangan jalur migrasi penduduk menjadikan Indonesia dilalui oleh jalur perdagangan dunia. Indonesia mengambil peluang untuk menyerap pengetahuan dan budaya, salah satunya adalah ke dalam proses pembuatan kain. Kegiatan menenun di kawasan Nusantara pada dasarnya memiliki banyak persamaan, yaitu peralatan, cara kerja dan hasil pengolahannya, tetapi di setiap daerah memiliki cirri khas tersendiri pada bentuk ragam hias, motif dan coraknya.

Definisi yang diuraikan oleh teoritisiteoritisi klasik pada umumnya hanya sedikit yang berbicara tentang budaya pada tataran hasil seni, tapi mereka lebih tertarik menguraikan budaya sebagai norma-norma, 
nilai-nilai dan gaya hidup. Teoritisi lebih pada pendekatan isu isu sosial budaya dari perspektif yang revelusioner. Mereka menitikberatkan pada perubahan budaya dimana masyarakat terlibat.

Para antropolog telah mendefinisikan kebudayaaan sebagai warisan simbol - simbol. Clifford Geertz (1973: 89), menyatakan bahwa suatu sistem konsepsi yang diwariskan dari generasi sebelumnya dan diekspresikan dalam bentuk simbolik; dengan bantuan kebudayaan manusia mengkomunikasikan, mengabadikan dan mengembangkan pengetahuan dan sikap terhadap kehidupan. Simbol-simbol tersebut dikomunikasikan, dilestarikan dan dikembangkan oleh manusia kepada generasi penerusnya melalui pengetahuan dan nilainilai kehidupan. Demikian halnya dengan Spradley (1979), bahwa kebudayaan dipahami sebagai sistem simbol yang dipakai manusia untuk memaknai kehidupan yang berisi orientasi nilai, sudut pandangan tentang dunia. Kroeber dan Kluckholn (1963) dikutip oleh Chris Jenks (1993), memberikan penjelasan bahwa simbol-simbol adalah media untuk menyebarkan sebuah sintesa yang lengkap dan produktif tentang kebudayaan yang membentuk prestasi khas kelompokkelompok manusia termasuk perwujudannya dalam bentuk artefak. Krober dan Kluckholn melanjutkan bahwa inti kebudayaan yang paling esensial terdiri dari ide-ide tradisional yang diderivasi dan diseleksi secara historis, terutama nilai-nilai sistem budaya yang dinisbahkan kepadanya, di satu sisi dapat dianggap sebagai produk tindakan, dan di sisi lain, sebagai elemen - elemen yang mengkondisikan tindak lanjut. Tradisi menenun dapat bertahan lebih lama dan masih eksis hingga saat ini di Pagatan karena nilai, aturan atau norma-norma yang diajarkan telah tertanam ke dalam kepribadian dan kemudian dilembagakan melalui pembinaan di dalam keluarga atau komunitasnya.

Tenun sebagai budaya terus berkembang seiring dengan perkembangan akal dan kebutuhan manusia, baik kebutuhan lahiriah maupun spiritual. Hal ini dapat dibuktikan dengan adanya fungsi tenun yang berbedabeda, antara lain: fungsi sosial, budaya, religious dan ekonomi. Ide pengetahuan berupa pandangan dan falsafah hidup tertuang ke dalam hasil karya. Pencerminan budaya dan perlambangan simbol dapat ditemukan di dalam pola hiasan (unsure dekoratif), ornamen dan motif kain tenun. Corak Tenun Pagatan diantaranya Bombang yang melambangkan gelombang-gelombang pantai, kapal dengan berbagai macam jenis kapal yang mencerminkan Suku Bugis yang mengarungi lautan, dan motif flora yang tumbuh di tepian Sungai Kusan yang indah.

Tradisi inipun mampu bertahan lama ketika masyarakat masih mempercayai adanya unsur-unsur mitos atau cerita yang berhubungan dengan proses pembuatan kain atau fungsi kain tersebut. Misalnya kain yang ditenun khusus untuk menyembuhkan penyakit sesuai dengan permintaan (Tenun Sarigading di Amuntai, Kalimantan Selatan), motif binatang yang tidak diperbolehkan untuk ditenun (Tenun Pagatan), cerita tentang keluarga kerajaan yang sangat menyayangi penenun dan mendapatkan tempat yang istimewa di istana. Unsur-unsur tersebut di satu sisi memiliki fungsi untuk menambah nilai kain. Konteks ini sesuai dengan pendekatan interpretative Clifford Geertz yang mempengaruhi kajian-kajian Antropologi sejak dekade 1970an hingga pertengahan 
1980an. Berdasarkan konsep kebudayaan demikian, dalam pendekatan interpretatif Geertz (1973:90), “agama” misalnya diteliti sebagai suatu "sistem kebudayaan" yang didefinisikan sebagai "suatu sistem simbol yang bertindak untuk memantapkan suasana hati (moods) dan motivasi (motivations) yang kuat, mendalam dan bertahan lama dengan cara mengformulasikan konsepsi-konsepsi mengenai tatanan dasar alam dan kehidupan, dan dengan menyelimuti konsepsi-konsepsi tersebut dengan suatu suasana yang faktual sehingga suasana hati dan motivasi yang ditumbulkannya terasa nyata".

Selanjutnya adalah konsep-konsep teoritis yang mencoba mengisi kelemahan definisi kebudayaan yaitu konsep practice, yang dikemukakan oleh Bourdieu (1977) pada akhir dekade 1970an, tetapi mulai menarik perhatian para Antropolog baru pada pertengahan 1980an (eg. Moore 1987, Ohnuki-Tierney 1995, Ortner 1984), bahkan ada artikel yang secara eksplisit membandingkan konsep kebudayaan Geertz dan Bourdieu (Lee 1988). Pokok pikiran teori praksis yang paling relevan dalam pembahasan ini adalah bahwa konsep "praksis" (practice) Bourdieu dibedakan dari konsep "tindakan" (action) yang merupakan salah satu konstruksi teoritis utama sosiologi Weber, yang diwariskan dalam pendekatan interpretatif Geertz. Kebudayaan yang terwujud sebagai praksis dan proses, akan juga berfungsi sebagai "konteks bagi tindakan si pelaku. Kebudayaan dalam arti konteks seperti ini menawarkan sejumlah konsepsi yang menjadi bahan pertimbangan si pelaku dalam menentukan tindakannya. Tidak dapat dihindari bahwa manusia dalam hidupnya selalu mengalami perubahan, demikian pula halnya dengan kebudayaan.

Perwujudan budaya juga bisa diwujudkan ke dalam perilaku interaktif yang menghubungkan antara pengetahuan "praxis" (bermanfaat bagi pembangunan) dengan persesi hermeneutic (ideologi dan falsafah hidup). Tradisi menenun bukan hanya berbicara tentang kapasitas individual yang mampu menuangkan ilmu pengetahuan yang dimilikinya, tetapi juga ada hubungan interaktif didalam kelompok mereka dan saling bertukar pikiran untuk menghasilkan tenun yang eksotis.

Ini tergambar dalam teori-teori kebudayaan dari beberapa antropolog Indonesia yang lebih menitikberatkan relasi kebudayaan dengan dinamika di masyarakat. Selo Soemardjan dan Soelaiman Soemardi (1964, 115) menyebutkan bahwa kebudayaan kebendaan atau kebudayaan jasmaniah (material Culture) merupakan hasil karya masyarakat yang diperlukan manusia untuk menguasai alam sekitarnya, rasa yang mewujudkan jiwa manusia yang mewujudkan kaidah-kaidah dan nilai-nilai sosial dalam masyarakat, cipta merupakan kemampuan mental, kemampuan berpikir yang menghasilkan filsafat dan ilmupengetahuan. Kemudian Koentjaraningrat (1985) mengartikan kebudayaan sebagai keseluruhan sistem gagasan, tindakan dan hasil karya manusia dalam rangka kehidupan masyarakat yang dijadikan milik manusia dengan belajar.

Selanjutnya definisi yang dekat dengan makna kompleks budaya mencoba melihat kebudayaan sebagai pengetahuan yang bersifat operasional, yaitu sebagai keseluruhan pengetahuan yang dipunyai oleh manusia sebagai mahluk sosial; yang isinya adalah 
perangkat-perangkat dan juga model-model pengetahuan yang secara selektif dapat digunakan untuk memahami dan menginterpretasi lingkungan yang dihadapi, dan untuk mendorong dan menciptakan tindakan-tindakan yang diperlukannya (Suparlan, 1986). Mempelajari suatu kompleks budaya dengan komponen elemen pembentuknya, tentu tidak dapat dipisahkan bagianya dari unit-unit sosia seperti keluarga, masyarakat, komunitas sosial, lembagalembaga sosial, serta stratifikasi dan struktur sosial yang dapat menjamin keberlangsungan hidup di dalam kompleks budaya tersebut. Di mana masing-masing bagian tersebut merupakan satu kesatuan banguan yang konstruktif sehingga tidak dapat dipisahkan satu dengan lainnya.

Hassan Shadily (1984, 82), membedakan makna kata culture di Indonesia dan barat, Indonesia memaknainya sebagai hasil bersama masyarakat bukan yang diciptakan oleh individu saja. Penemuan-penemuan mungkin diciptakan oleh seorang individu sebagai anggota masyarakat yang kemudian berkembang dan dipergunakan dalam kehidupan masyarakat tersebut. Operasional ini dapat dimaknai bahwa tradisi menenun secara khusus memerlukan proses pengerjaan yang bertahap dan runtun. Dari awal pemintalan benang, penenun harus memiliki pengalaman tertentu. Demikian langkah selanjutnya, misalnya mengikat, penenun harus mengetahui hitungan benang untuk mendapatkan motif sesuai keinginannya. Langkah berikutnya adalah mewarna yang menentukan warna dasar dan warna motif. Kesemua langkah memerlukan pengetahuanpengetahuan khusus.
Teoritis - teoritis pada masa modern dan postmodern lebih mengedepankan fragmentasi - fargmentasi budaya dengan perubahan di masyarakat karena era globalisasi. Walaupun perbedaan terjadi, penulis masih menemukan persamaan-persamaan teoritis yang diuraikan. Teori-teori ini dipilah dan disesuaikan dengan konteks tradisi menenun yang telah diuraikan sebelumnya. Christopher Jenks (1993) membedakan makna kata "budaya" yang sekarang dipakai ke dalam 4 pengertian utama yaitu pertama, budaya kadang dilihat sebagai keadaan pikiran saat bergerak menuju gagasan kesempurnaan, tujuan atau aspirasi pencapaian individu atau emansipasi individu. Kedua budaya dekat hubungannya dengan ide peradaban dimana beberapa masyarakat lebih berbudaya atau beradab dari yang lain. Ketiga, budaya sebagai kumpulan seni dan karya intelektual dalam satu komunitas manapun yang terkadang dimaknai sebagai budaya tinggi. Keempat, budaya sebagai cara hidup masyarakat.

Definisi keempat di atas berhubungan dengan definisi yang diutarakan Ralph Linton (1945) dikutip oleh Jencks bahwa budaya dalam masyarakat adalah cara hidup anggotaanggotanya, kumpulan gagasan - gagasan dan kebiasaan-kebiasaan yang mereka pelajari, bagikan dan kirimkan melalui generasi ke generasi. Definisi tersebut adalah satu yang paling sering digunakan oleh para sosiologis kontemporer dimana budaya dalam hal ini hampir menggabungkan seluruh materi yang dikaji dalam sosiologi (Haralambos, Holborn, Chapman \& Moore, 2013).

Haralambos, Holborn, Chapman \& Moore kemudian menjelaskan bahwa dalam skala yang luas, budaya menentukan bagaimana anggota masyarakat berpikir dan merasa, ini 
mengarahkan gerakan-gerakan mereka dan mengartikan penampakan mereka dalam kehidupan.

Selanjutnya Anthony Giddens (1991 : 31) mengemukakan :

When we use the term in ordinary daily conversation, we often think of "culture" as equivalent to the higher things of the mind" art, literature, music and painting... the concept includes such activities, but also far more. Culture refers to the whole way of life of the members of a society. It includes how they dress, their marriage customs and family life, their patterns of work, religious ceremonies and leisure pursuits. It covers also the goods they create and which become meaningful for them bows and arrows, ploughs, factories and machines, computers, books, dwellings.

Rosana (2017) menyimpulkan isi utama kebudayaan adalah berupa sistem pengetahuan untuk menyimpulkan gagasan dari hasil pengamatan alat indra, nilai sebagai kumpulan yang selalu diperlihatkan melalui perilaku manusia tentang baik atau buruk, pandangan hidup sebagai pedoman yang dianut oleh golongan atau individu tertentu dalam masyarakat, religi atau agama yang berkaitan dengan kenyataan yang tidak dapat ditentukan secara empirik, persepsi berupa pandangan seseorang yang bersifat individu terhadap sesuatu masalah yang berkaitan dengan keadaan yang terjadi di masyarakat, serta etos atau watak khas yang terpancar dari suatu kebudayaan.

Teori klasik yang diuraikan oleh Edward Burnett Tylor pada abad 19 pun masih mendapatkan tempat hingga kini. Tylor mendiskripsikan nilai-nilai adat dan budaya sebagai sekumpulan unsur-unsur berupa adat istiadat, hukum, kepercayaan, moralitas dan sistem pengetahuan. Karwita $(2007,10)$ menyebutkan bahwa aktivitas masyarakat yang berbeda-beda dipengaruhi oleh nilai budaya dan adat istiadat yang diciptakan oleh leluhur atau pendahulunya.

Tradisi menenun berisikan pengalaman manusia yang universal dengan wujud kebudayaannya yang khusus dan berbeda sesuai dengan situasi dan lokasi dimana manusia itu menuangkan ide, pengetahuan dan gagasannya. Tradisi ini pun mengalami dinamika dan perubahan-perubahan yang berkelanjutan dipengaruhi faktor di internal penenun ataupun eksternal yang mempengaruhinya. Ini bisa dilihat dari berubahnya simbol-simbol atau motif-motif yang dituangkan ke dalam tenun. Tren motif tersebut dipengaruhi oleh perkembangan pengetahuan yang dimiliki dan proses belajar individu ataupun interaktif di dalam kelompoknya.

Walaupun demikian terdapat unsur-unsur yang stabil dalam tradisi menenun yang tetap tak lekang untuk dipakai. Unsur tersebut adalah nilai-nilai falsafah dari proses pembuatannya, teknik-teknik atau dalam sebuah teori sebelumnya sebagai langkahlangkah operasional serta makna dari motif yang bersifat stabil. Helaian tenun adalah hasil dari ide-ide atau gagasan manusia penuh dengan estetika keindahan serta cara pembuatannya yang rumit karena harus melibatkan perasaan, emosi, intensitas pemikiran serta gambaran-gambaran imajinatif tentang alam tempat tinggalnya. Unsur dasar ekspresi manusia tidak bisa dilepaskan dari hasil karya seni. Intensitas 
pemikirannya langsung terhubungkan kepada orientasi nilai di dalam adat istiadat dan tradisi yang belaku di masyarakatnya.

Teori-teori kebudayaan demikian membantu kita memahami secara lebih rinci implikasi globalisasi terhadap kebudayaan lokal yang menjadi pokok bahasan tulisan ini ini. Studi-studi yang disajikan bertumpu pada teori-teori yang menunjukkan suatu proses yang akhir - akhir ini sedang dan akan terjadi, padahal sejak masa lalu setiap masyarakat di muka bumi ini merupakan "masyarakat global" (Sahlins 1994: 387).

\section{Identitas Budaya}

Identitas Bugis Pagatan masih mampu diidentifikasi melalui tradisi - tradisi budaya yang masih mereka lakukan. Secara mendasar sekurang - kurangnya dapat dilihat tampilan orang Bugis Pagatan yang membedakan dengan suku lainnya di Tanah Bumbu yaitu berupa bahasa, tradisi menenun mereka, adat istiadat atau pada saat berpakaian yang menggunakan ciri-ciri tertentu. Maka sebelum menuju kepada pembahasan mengenai pengaruh era globalisasi terhadap tradisi menenun, penulis memandang perlu untuk menyajikan teori - teori identitas budaya. Teori - teori ini dapat menjadi dasar mengkaji fragmentasi saat ini yang selanjutnya akan dihubungkan dengan pembahasan isu globalisasi dan perubahan budaya (masuknya budaya global dan popular).

Konsep identitas menjadi semakin mencuat dalam sosiologi. Sosiolog pada awalnya jarangmenggunakan konsep ini, meskipun studi yang dilakukan sering menyiratkan teori identitas. Mereka selama ini mengecilkan arti penting dari identitas identitas seperti gender, seksualitas dan etnis. Beberapa sosiolog percaya bahwa penelitian seperti ini digerakkan dengan konsep identitas modern. Dalam pembahasan pada 'Identitas dan Budaya', Haralambos dan Holborn (2013, 729) menyebutkan bahwa konsep identitas berkaitan erat dengan budaya, identitas dapat dibentuk melalui budaya-budaya dan sub-sub budaya di mana orang orang tersebut berasal dan beraktivitas. Namun, teori yang berbeda tentang identitas melihat hubungan antara budaya dan identitas dengan cara yang berbeda. Mereka dipengaruhi oleh teori - teori modern tentang budaya dan identitas yang lebih melihat identitas langsung berasal dari keterlibatan budaya-budaya dan sub-sub budaya tertentu. Teori-teori postmodern cenderung menitikberatkan pada kompleksitas menjadi seseorang yang berasal dari etnis yang berbeda atau asal kewarganegaraannya yang mengartikan identitasnya.

Stuart Hall (1990: 393) mengemukakan dua pemikiran terkait identitas budaya. Pemikiran pertama menyatakan bahwa identitas budaya merupakan budaya bersama yang dimiliki oleh sekelompok orang yang memiliki sejarah dan keturunan yang sama. Dalam konteks ini, identitas budaya merefleksikan pengalaman sejarah dan kode budaya yang sama dimana cenderung stabil dan tidak berubah. Sedangkan pemikiran kedua menyatakan bahwa identitas budaya tidak sepenuhnya tetap melainkan bisa berubah tergantung bagaimana memposisikan dan menjadi subjek sejarah, budaya, dan kekuasaan yang terus bermain. Dengan kata lain pemikiran pertama menyatakan bahwa identitas budaya adalah being, sedangkan pemikiran kedua menyatakan identitas budaya adalah becoming. Hall kemudian sampai pada 
kesimpulan bahwa identitas budaya merupakan suatu produksi yang tidak pernah selesai, melainkan selalu dalam proses identifikasi dalam konteks sejarah dan budaya.

Paul Willis (2000) menyatakan bahwa individu-individu dan kelompok-kelompok memikul tanggung jawab dan merasa harus turun tangan dalam membentuk dirinya sebagai sesuatu yang lebih dari sekedar proses penerimaan pasif atau tidak sadar atas identitas ditentukan secara historis dan sosial (sekedar menjadi kelas pekerja, hitam atau putih, muda atau tua, dan lain-lain). Setiap orang ingin memiliki, atau menciptakan, atau dipandang memiliki signifikansi kultural.

Li (2000) kemudian berusaha untuk menggunakan pemikiran Hall dalam penelitiannya terhadap artikulasi identitas orang Lindu dan Lauje di Sulawesi Tengah Indonesia dan mendapat kesimpulan bahwa identitas budaya sekelompok orang dipengaruhi oleh sejarah, budaya, geografi, politik (kekuasaan), dan lain-lain, faktorfaktor ini juga yang mempengaruhi artikulasi identitas sekelompok orang terlihat jelas atau tidak jelas.

Olayode (2005) mengemukakan dalam tulisannya bahwa identitas kultural dapat ditelaah melalui gaya hidup penduduk asli, misalnya tentang bagaimana penduduk setempat menyelenggarakan pesta adat, memperingati peristiwa siklus hidup dan hal hal lain yang unik sebagai cultural impressions yang dianggap mewakili identitas kultural.

Dalam sebuah tulisan tentang Afrika dengan judul Beyond Tribalism: Seeking a New Cultural Identity for East Africa (1999) dikemukakan bahwa identitas kultural dapat ditelaah melalui gaya hidup penduduk asli, misalnya tentang bagaimana penduduk setempat menyelenggarakan pesta adat, memperingati peristiwa siklus hidup, dan hal hal lain yang unik sebagai cultural impressions yang dianggap mewakili identitas cultural. Sekurang-kurangnya jika seseorang ingin mengenal identitas orang Sunda (misalnya), ia dapat melihatnya melalui tampilan individual yang unik, seperti bahasa, adat istiadat, gerakgerik anggota tubuh waktu menari dan berpakaian.

Liliweri memberikan gambaran rincian karakteristik atau ciri-ciri sebuah kebudayaan yang dimiliki oleh sekelompok orang yang kita ketahui batas-batasnya tatkala dibandingkan dengan karakteristik atau ciriciri kebudayaan orang lain, yaitu pertama identitas budaya merupakan pusat penampilan kepribadian kita. Kita akan menjadi lebih sadar tentang identitas budaya sendiri manakala kita hidup di dalam kebudayaan orang lain, kedua, identitas budaya kita kadang-kadang bisa bertahan dalam konteks social yang selalu berubah dan ketiga, identitas budaya merupakan sesuatu yang bermuka banyak (Liliweri, 2002:82).

Selanjutnya Stephen Frosch menjelaskan pendapatnya bahwa identitas tergambar dari budaya namun tidak langsung dibentuk oleh budaya. Teori sosiologis dan psikologis barubaru ini telah menekankan bahwa identitas seseorang sebenarnya adalah sesuatu yang multipel dan berpotensi cair, dibangun melalui pengalaman dan bahasa yang dikodekan. Dalam mengembangkan identitas mereka, orang memanfaatkan sumber daya yang tersedia secara budaya di jaringan sosial langsung mereka dan di masyarakat secara keseluruhan. Oleh karena itu, proses konstruksi identitas menjadi salah satu 
kontradiksi dan disposisi lingkungan sosiokultural di sekitarnya memiliki dampak besar (Frosch, 1999).

Identitas budaya tidak terlepas dari faktor psikologis seseorang atau individu terhadap kelompoknya. Dengan kata lain adanya perasaan memiliki (sense of belonging) yang menjadi faktor penting yang berperan dalam pembentukan identitas. Menurut Rice (1990, 202) identitas budaya adalah jumlah keseluruhan dari perasaan seseorang atau anggota kelompok terhadap simbol-simbol , nilai nilai dan sejarah umum yang membuat mereka dikenal sebagai kelompok yang berbeda. Selanjutnya Phinney menurut Dacey and Kenny $(1997,191)$ adalah sebuah bagian dari konsep diri seseorang yang berasal dari pengetahuan dan perasaan seseorang yang menjadi bagian dari kelompok budaya tertentu. Definisi lain tentang identitas budaya diungkapkan oleh Dusek (1996 :162) adalah merujuk kepada seberapa besar seseorang merasa sebagai bagian dari kelompok budaya/etnis tertentu dan bagaimana hal tersebut mempengaruhi perasaan, persepsi dan perilakunya.

Menurut Ting- Toomey (1999:30), identitas kultural merupakan perasaan (emotional significance) dari seseorang untuk ikut memiliki (sense of belonging) atau berafiliasi dengan kultur tertentu. Masyarakat yang terbagi ke dalam kelompok-kelompok itu kemudian melakukan identifikasi kultural yaitu setiap orang mempertimbangkan diri mereka sebagai representasi dari sebuah budaya tertentu. Masyarakat yang terbagi ke dalam kelompok-kelompok itu kemudian melakukan identifikasi kultural (Raharjo, 2005:2). Identitas kultural ini, menurut Roger \& Steinfatt (1999:97), akan menentukan individu-individu yang termasuk dalam ingroup dan outgroup secara kultural. Bagaimana mereka berperilaku, sebagian ditentukan oleh apakah mereka termasuk ke dalam budaya tertentu atau tidak.

\section{Masuknya Budaya Global}

Kebudayaan mengisi dan menentukan jalannya kehidupan manusia, walaupun hal iitu kurang disadari oleh manusia sendiri. Gejala tersebut dapat diterangkan bahwa walaupun kebudayaan merupakan atribut manusia, namun tak mungkin seseorang mengetahui dan meyakini seluruh unsur-unsur kebudayaan itu sendiri. Dengan demikian, pertentangan yang dimaksud di atas adalah pertentangan yang mungkin timbul dari masing-masing unsur-unsur yang membentuk kebudayaan dan perubahan yang dialami kebudayaan.

Tidak dapat dipungkiri bahwa kebudayaan selalu berubah seiring dengan perkembangan yang terjadi di dalam masyarakat. Penduduk dunia memasuki era modernitas yang ditandai oleh perubahan, inovasi dan kedinamisan. Aktivitas perekonomian dunia yang semakin cepat dengan cakupan yang semakin luas melahirkan globalisasi yang membawa perubahan signifikan dalam kehidupan berbudaya. Scorey (2003) mengartikan globalisasi sebagai nama yang diberikan kepada hubungan-hubungan kompleks yang memberikan karakter pada abad 21. Hal ini ditujukan kepada arus global pada modal, komoditi, dan komunikasi yang melintasi perbatasan teritori. Globalisasi tidak hanya tentang ekonomi, namun berhubungan juga dengan makna budaya. Pada masa lampau budaya-budaya dibelahan bumi terpisah satu 
sama lain. Mereka dipisahkan oleh waktu dan tempat. Kebudayaan-kebudayaan introvert, yang telah begitu banyak muncul dalam perjalanan sejarah dan memburamkan kebudayaan translokal, semakin terdesak mundur, sementara itu kebudayaan translokal yang terbentuk sari berbagi unsur semakin mengemuka (Pieterse, 1995: 62).

Bagi Giddens (1991) dikutip oleh Chris Baker (2000), institusi-institusi modernitas terdiri dari kapitalisme, industrialisme, pengawasan, negara-bangsa dan kekuatan militer. Giddens membayangkan institusi modernitas adalah sebuah mesin penggilas yang memiliki kekuatan luar biasa yang tak terkendalikan. Konsep modernitas dimulai dari Eropa Barat yang menggelinding ke penjuru dunia dan dianggap berporos pada dunia Barat. Berman (1982) menyebutkan bahwa kemunculan modernisasi melahirkan manusia yang terikat dengan modernisasi dimana manusia mengalami modernisme kultural yang penuh dengan perubahan dan ketidakpastian. Kehidupan manusia dirubah oleh industri, teknologi dan sistem komunikasi.

Giddens melihat modernitas membawa kehidupan yang lebih berisiko dan penuh keraguan sehingga segala hasil penciptaan manusia memiliki peluang untuk diperbaiki (Giddens 1990, 1994). Ambiguitas, keraguan, resiko dan perubahan terus menerus yang menjadi ciri-ciri pertanda modernisme termanifestasikan dalam pembentukan diri (Chris Barker, 2000, 142). Clifford (1992) memiliki pendapat bahwa kita harus menempatkan ulang kebudayaan dengan metafora perjalanan daripada metafora lokasi, dimana Inggris memiliki penduduk yang berlatarbelakang dari suku bangsa yang berbeda demikian pula Amerika.
Globalisasi seringkali dipandang sebagai unsur (agent) sekaligus bentuk dari cultural imperialism. Pandangan demikian dapat diamati melalui kian memudarnya anasiranasir budaya tradisional dan digantikan dengan anasir-anasir baru yang notabene dari barat, mulai dari mode pakaian, menu makanan, corak arsitektur, musik, bahasa, system ekonomi, dan sistem politik. Globalisasi mengacu kepada penyempitan dunia secara intensif dan peningkatan kesadaran kita atas dunia, yaitu semakin meningkatnya koneksi global dan pemahaman kita atas mereka. Penyempitan dunia ini dapat dipahami dalam konteks institusi modernitas, sementara intensifikasi kesadaran dunia secara refleksif dapat dipresepsikan lebih baik secara budaya (Barker, 2005:113).

Budaya-budaya global menembus tatanan lokalberwujudke dalam berbagai bentukbentuk popular yang disajikan melalui alatalat komunikasi. Bentuk-bentuk populer tersebut berkembang ke seluruh wilayah tanah air membawa fenomena-fenomena baru. Di masyarakat sendiri terjadi proses perubahan menyikapi berkembangnya globalisasi. Bahreint T. Sugihen (1997) menyebutkan tahapan utama proses perubahan yaitu berawal dari diciptakannya atau lahirnya sesuatu, mungkin sesuatu yang diidamkan atau sesuatu kebutuhan, yang kemudian berkembang menjadi suatu gagasan (idea, concept) yang baru. Bila gagasan itu sudah menggelinding seperti roda yang berputar pada sumbunya, sudah tersebar di kalangan anggota masyarakat, proses perubahan tersebut sudah memasuki tahapan yang kedua. Tahapan berikutnya sebagai tahapan ketiga yang disebut sebagai hasil (result, concequences) yang merupakan perubahan-perubahan yang 
terjadi dalam sistem sosial yang bersangkutan sebagai akibat dari diterimanya atau ditolaknya suatu inovasi.

Perubahan sosial adalah perubahan yang terjadi dalam masyarakat yang meliputi perubahan struktur, sistem, dan organisasi sosial sebagai akibat adanya modifikasi polapola kehidupan manusia, yang dipengaruhi oleh adanya kebutuhan intern dan eksteren masyarakat itu sendiri. Perubahan itu terjadi secara terus menerus, oleh karena itu perubahan sosial merupakan fenomena yang kompleks yang menembus berbagai tahapan dari kehidupan sosial. Perubahan sosial sebagaimana dikemukakan oleh Gillin \& Gillin dalam Selo Soemardjan dan Soeleman Soemardi merupakan suatu variasi dari caracara hidup yang telah diterima baik karena perubahan-perubahan kondisi geografis kebudayaan material, komposisi penduduk, ideologi maupun karena adanya difusi atau penemuan-penemuan baru dalam masyarakat tersebut.

Kehadiran budaya popular dalam kehidupan masyarakat lokal pada kondisi tertentu dapat digunakan untuk melihat atau menggambarkan gaya hidup dan kehidupan yang sedang dialami. Budaya popular yang datang dari luar bercampur dengan budaya lokal menjadi satu dalam medium yang dikonsumsi setiap hari oleh masyarakat. Pertentangan-pertentanganpun timbul dari masing-masing unsur-unsur yang membentuk kebudayaan serta perubahan yang dialami kebudayaan. Unsur yang berubah ini biasanya berbeda derajat perubahannya sesuai dengan hakikat kebudayaan, seperti teknologi, lebih bersifat terbuka akan proses perubahan dibandingkan dengan unsur-unsur rohaniah seperti struktur keluarga, kode moral, sistem kepercayaan, dan lain-lain. Kebudayaan mengisi dan menentukan jalannya kehidupan manusia, walaupun hal itu kurang disadari oleh manusia sendiri. Barker menyatakan bahwa bentuk identitas dapat berubah dan terkait dengan berbagai konteks sosial dan kultural. Gagasan bahwa identitas ini bersifat plastis dipertegas oleh argumen yang disebut dengan antiesentialisme. Identitas adalah konstruktif diskursif yang berubah maknanya menurut ruang, waktu dan pemakaian (Chris Barker: 2000, 175 - 176).

\section{Tenun Pagatan Sebagai Hasil Sebuah Negosiasi}

Di tengah budaya global seperti saat ini, kompetisi dengan menggunakan standar kualitas internasional semakin nyata di hadapan kita. Semua aspek kehidupan seakan dipaksa untuk mengikuti standar yang bersifat global, mulai dari produk barang dan jasa sampai gaya hidup (life style) keseharian. Praktik kehidupan seperti itu secara mudah melanda bangsa kita. Produk teknologi global memang tak terbendung saat ini. Globalisasi membuat kita terjerat jauh ke luar dari fisik kita dan masuk ke dalam arus global atau proses kultural global, integrasi dan disintegrasi kultural yang menjadikan metafora perjalanan begitu relavan karena semua yang lokal kini dipengaruhi oleh tempat yang jauh di sana (Barker, 2000: 120). Proses globalisasi menyentuh hingga ke masyarakat lokal, pedesaan dan wilayah terpencil yang dulu sulit ditembus. Hebdige (1990) menggambarkan kosmopolitanisme sebagai aspek kebudayaan lokal terpencil digabung dengan institusi-institusi yang mendukung percepatan globalisasi sehingga menyebabkan 
persaingan, pertemuan dan percampuran budaya.

Komunitas pengrajin Tenun Pagatan berusaha untuk beradaptasi dengan seleraselera pasar. Di sisi yang lain mereka seperti dituntut untuk menghasilkan produk-produk yang memiliki kesempurnaan yang lebih dari produk kebudayaan yang lain. Di dalam hubungan di atas, maka biasanya diberikan nama "peradaban" (civilization) kepada kebudayaan yang telah mencapai taraf perkembangan teknologi yang sudah lebih tinggi. Selain itu, peradaban digunakan untuk menyebut unsur-unsur kebudayaan yang maju dan indah (kesenian, ilmu pengetahuan, sopan santun pergaulan, organisasi kenegaraan, dan sebagainya). Peradaban sering dipakai untuk menyebut suatu kebudayaan yang mempunyai sistem teknologi, sistem ilmu pengetahuan, seni bangunan, seni rupa, dan sistem kenegaraan, serta masyarakat kota yang maju dan kompleks. Atas nama peradaban komunitas pengrajin Tenun Pagatan melakukan komodifikasi (berinovasi) untuk memenuhi selera-selera pasar.

"Development of taste is a key feature of modern culture. Taste only develops whe make choices about people have enough resources about what they consume. In early modernity only the highest classes could do this, but as modernity progressed the possibility of choosing what to consume spread to all classes. This does not undermine hierarchies of taste. The taste of higher social classes is still valued above that of lower classes"(Crook et al).

Sulaksono (2015), untung masih banyak orang yang menghargai karya seni tradisi, sehingga pemasarannya masih dapat memenuhi kebutuhan masyarakat golongan tertentu. Tekstil dan tenun tradisi harus dilihat ke dalam teknik pembuatan, fungsi, dan langgam (corak budaya dan kurun-kurun waktu tertentu dimana suatu tradisi dengan keragaman budayanya penah begitu dominan pemakaiannya di dalam strata sosial dan golongan masyarakat tertentu.

Kain yang sebelumnya dihasilkan oleh tenun gedok dalam satu bulan hanya sehelai, dengan Alat Tenun Bukan Mesin (ATBM) kain mencapai 20 meter atau 10 helai kurang dari satu bulan. Bahan benang yang digunakan tentu mutunya jauh berbeda, benang katun yang tebal tidak mampu ditenun di alat gedok yang memiliki sisir (alat memasukan benar) yang halus. Benang sejenis itu hanya dapat ditenun di ATBM, demikian pula sebaliknya, benang yang haluspun akan patah apabila ditenun di ATBM.

"this undermines aesthetic values and threatens the purity of high art. It bring the masses an inferior and debased culture which then threatens the unique qualities of high art"

Perkembangan keberadaan produk-produk tenun di Pagatan sekarang merupakan fenomena postmodernisme yang dapat menggambarkan ciri kebebasan dari kategorisasi dan prinsip-prinsip sebelumnya. Tenun sutra yang awalnya berbentuk sarung untuk laki-laki saat ini dihasilkan dalam helaian panjang yang sesuai untuk perempuan. Kemudian motif-motif pada songket dan sutra Pagatan, saat ini banyak diaplikasikan pada tenun ATBM. Warna-warna yang dulunya 
terang dan berani seperti kebanyakan tenun Bugis berubah menjadi lembut.

\section{Peran Eksternal}

Uraian-uraian sebelumnya mampu menggambarkan peran eksternal yang cukup kuat untuk memberikan dinamika perubahan di Pagatan. Pemerintah Kabupaten Tanah Bumbu mampu menjadikan produk-produk kebudayaan Bugis Pagatan sebagai komoditas yang bisa dikembangkan sejalan dengan kebijakan mereka di industri pariwisata. Dengan ditetapkannya Tenun Pagatan sebagai Produk Unggulan Kabupaten Tanah Bumbu, pada akhirnya dapat dikaji ulang intervensiintervensi pemerintah untuk menindaklanjuti penetapan tersebut.

Pemerintah memiliki keleluasaan bergerak memasuki ruang-ruang privasi penenun dengan mengatasnamakan keunggulan tenun Pagatan yang akan membedakannya dengan tenun-tenun lain di Nusantara. Tema-tema kelautan sebenarnya telah ada dalam motif dikembangkan kembali untuk memperlihatkan keunggulan potensi kelautan di Kabupaten Tanah Bumbu.

Budaya kompetitif saat ini cukup terasa di dalam komunitas pengrajin terbukti dengan semakin bervariasinya corak yang dihasilkan dengan kualitas yang berbeda dan tumbuhnya UKM-UKM baru di desa Manurung dan Mudalang sebagai sentra produksi tenun di Pagatan. Globalisasi membawa mereka yang memahami kemajuan komunikasi sebagai momen yang bermanfaat. Pengrajin mengetahui hal hal yang tren tentang kain dan fashion yang diadaptasi ke dalam format budaya lokal mereka. UKM-UKM tersebut dibentuk untuk memahami kemauan pasar yang menginginkan perpaduan-perpaduan unik dan menarik.

Pemetaan Pengrajin Tenun Pagatan tahun 2015 memperlihatkan dinamika yang positif pada tingkat kapasitas pengrajin. Pengrajin yang dulunya hanya memiliki kemampuan sebagai pelaku dalam proses industri, sekarang mereka memahami sistem manjemennya secara bertahap dari pengadaan bahan benang, modal yang diperlukan, bahkan mengelola tim yang masuk didalam proses menenun hingga distribusinya. Pengrajin-pengrajin baru yang berusia relatif muda pun lahir. Ini membuktikan bahwa industri Tenun Pagatan mulai dilirik untuk menjadi mata pencaharian mereka.

\section{Simpulan}

Penelitian ini menunjukkan bahwa tenun pagatan yang dihasilkan pengrajin tenun pagatan merupakan hasil sebuah negosiasi dari budaya dan tradisi Bugis Pagatan dan budaya global. Pemerintah Daerah Kabupaten Tanah Bumbu berperan dalam penguatan identitas budaya Bugis Pagatan.

Secara garis besar, manfaat yang diharapkan dari penulisan ini adalah: pertama, memberikan sumbangan akademik untuk kajian tentang produk - produk kebudayaan tertentu, khususnya suku - suku pendatang di Kalimantan Selatan yang memberikan dinamika dan perubahan dalam bidang sosial, ekonomi, budaya dan politik. Dengan melakukan kajian ini, bukan saja akan mengisi celah baru kajian budaya, tetapi diharapkan juga memberikan sumbangan konseptual untuk memahami perubahan yang dialami dan strategi yang baik untuk menyikapinya. 
Kedua, dari segi praktis, penelitian ini diharapkan dapat memberikan manfaat bagi pemerintah daerah setempat yang merumuskan berbagai strategi pembangunan untuk memaksimalkan potensi di daerahnya khususnya dalam bidang pengembangan industri lokal. Hasil studi ini menjadi bahan pertimbangan dalam mendesain program yang buttom - up dan benar - benar kontekstual untuk mendorong keterlibatan masyarakat. Tulisan ini diharapkan mampu memberikan gambaran awal mengenai produk-produk kebudayaan dari Bugis Pagatan dan perkembangannya serta dapat memberikan masukan bagi penelitian lanjutan yang terkait dengan keberadaan mereka di Kabupaten Tanah Bumbu.

\section{Daftar Pustaka}

Alam, B (1998) Globalisasi dan Perubahan Budaya: Perspektif Teori Kebudayaan. Widyakarya Nasional "Antropologi dan Pembangunan " (p. 9). Jakarta: ANTROPOLOGI INDONESIA Vol . 54.

Aleksandar KSL (2007) The cluster approach and SME competitiveness: A Review. Journal of Manufacturing Technology Management Vol. 18 No. 7 , 818-835.

Amalia, AD \& Syawie, M (2015) Pembangunan Kemandirian Desa Melalui Konsep Pemberdayaan : Suatu Kajian dalam Perspektif Sosiologi. Sosio Informa Vol. 1, No. 02, , 175 - 188.

Ammarell, G (2002) Bugis Migration and Modes of Adaptation to Local
Situstions. University of Pittsburgh- Of the Commonwealth System of HigherEducatio , 51 - 67.

Barker, C (2000) Cultural Studies, Theory and Practice. London: Sage Publications.

Boehm, A \& Cnaan, R (2012). Towards a Practice-based Model for Community Practice: Linking Theory and Practice. Departmental Papers (SPP) School of Social Policy and Practice 3.

Gani, IP (2016) Pembelajaran Ekonomi Berbasis Budaya Lokal Bugis dalam Pendidikan Keluarga. National Conference On Economic Education, (pp. 638 - 648). Malang.

Haralambos, M; Holborn; Chapman, MS; and Stephen Moore (2013) Sociology Themes and Perspectives 8th Edition. London: Collins.

Hudayana, B (2000) Kebudayaan Lokal dan Pemberdayaannya. Jurnal Ilmu Sosial dan Ilmu Politik Vol. 3 No. 3 , 285 - 307.

Ida, R (2017) Budaya Populer Indonesia Diskursus Global / Lokal dalam Budaya Populer Indonesia. Surabaya: Airlangga University Press.

Irianto, S \& Margaretha, R (2011) Piilpesenggiri: Modal Budaya Dan Strategi Identitas Ulun Lampung. MAKARA, SOSIAL HUMANIORA , 140 -150 .

Jefferies, J (2013) Women and Middle Eastern Textiles Globalization and the Impact on 
Knowledge and Skills. Textile, Volume 11, Issue 2, , 122 - 127.

Jenks, C (1993) Culture. London: Routledge.

Lamont, M (1987) How to Become a Dominant French Philosopher: The Case of Jacques Derrida. American Journal of Sociology, Vol. 93, No. 3 , 584 - 622.

Lubis, AY (2016) Postmodernisme Teori dan Metode. Jakarta: PT Raja Grafindo Persada.

Mas'udi (2014) Posmodernisme dan Polemik Keberagaman Masyarakat Modern (Antitesis Posmodernisme atas Dinamika Kehidupan Modernisme). Fikrah, Vol. 2, No. 1, , 229 - 251.

Matsenjwa, GN \& Musiiwa, E (2016) The Globalization of the Rural Swazi Weaver:Lavumisa Women in the Commercial Handicraft Industry, 19812013. Journal of International Women's StudiesVol. 17 Issue 1 , 102 - 116.

Meyer, JW (2007) Globalization Theory and Trends. International Journal of Comparative Sociology Vol 48(4): , 261 $-273$.

Ntseane, P (2004) Being a Female Entrepreneur in Botswana: Cultures, Values, Strategies for Success. Gender and Development, Vol. 12, No. 2, , 37 43.
Rosana,E (2017) Dinamisasi Kebudayaan Dalam Realitas Sosial. AlAdYaN/Vol.XII, NO.1 , 16 - 30.

Saleh, M. H. (2015). Dinamika Masyarakat Perbatasan (Eksistensi Perantau Bugis di Pulau Sebatik Kalimantan Utara:Perspektif Cultural Studies). Jurnal Borneo Administrator/Volume 11/No. 1, 31 - 48.

Suloksono, DP (2015) Wastra Tenun Kalimantan Selatan. Banjarmasin: Pustaka Banua.

Suryawan, N (2016) Adaptasi Etnik Bugis Mempertahankan Eksistensinya dalam Era Globalisasi di Kampung Islam Kepaon, Denpasar Selatan. Seminar Nasional Riset Inovatif (Senari) ke - 4, (pp. 555 - 564). Denpasar.

Syukur, M (2016) Social Network of Bugis Weavers at Wajo Regency, South Sulawesi. Komunitas, International Journal of Indonesian Society and Culture , 155 - 168.

Tapp, N \& Lee, GY (2010) The Hmong of Australia Culture and Diaspora. Canberra, Australia: ANU E Press.

Wiyatmoko, A (2011) Identitas dan Prospek Resistensi dalam Globalisasi. Global \& Strategis, Edisi Khusus, 271 - 287. 